\title{
THE RELATIONSHIP BETWEEN BENEFITS AND CONSTRAINTS PERCIEVED WITH THE HABIT OF SMOKING IN HEALTH PROFESSIONALS IN LATAMBAGA SUB-DISTRICT KOLAKA DISTRICT
}

\author{
Martina Pingak ${ }^{1}$, Tasnim Tasnim ${ }^{2}$, Herianto Wahab ${ }^{3}$ \\ ${ }^{123}$ Master of Public Health Study Program, Universitas Mandala Waluya, \\ In Kendari, Southeast Sulawesi Province, Indonesia
}

Corresponding Author : Martina Pingak

Email : martinapingak03@gmail.com

\begin{abstract}
Background:From the results of a preliminary study conducted at the Kolakaasi Health Centre and Latambaga Health Centre, through direct interviews and direct observation that out 10 (ten) health workers who were observed, 7 (seven) were active smokers and 3 (three) were nonsmokers. Therefore, through this research, the researcher wants to conduct in-depth research related to the smoking habits of health workers in which a health worker should be able to provide a good example for the community.

Methods:This research is an analytical survey using a cross-sectional approach. The population in this study were 106 all health workers in Latambaga District, with a sample size of 84 respondents using the sampling techniqueSimple random sampling.

Results:Based onanalysis of the chi square test for the benefit variable has a significance level of $95 \%$ was obtained $\mathrm{p}$-value $=0.000<\alpha=0.05$, so Ho is rejected. The constraint variable based on the chi square test analysis has a significance level of $95 \%$, the obtained p-value $=0,000<\alpha=$ 0.05 , so Ho is rejected.
\end{abstract}

Conclusion:There is a significant between perceived benefits and constraints with habits smoking health personnel in the Latambaga Sub-District, Kolaka Regency.

Key words: Benefits, Constraints, Smoking habits, Health workers 


\section{INTRODUCTION}

The World Health Organization (WHO) explains that smoking kills six million people per year worldwide, including more than 600,000 passive smokers. Most developing countries have low rates of quitting smoking, despite various antismoking campaigns around the world. Based on this latest data, the number of smokers worldwide increased by almost 250 million between 1980 and 2012. The number of smokers worldwide increased to nearly one billion people and in a number of countries including Indonesia and Russia more than half of the total male population smoked every day(1).

The factors that cause a person to tend to smoke are uncertain. All of this indirectly indicates the weak awareness in each individual and the mindset they have, so that without thinking they fall into the habit of smoking.(2). So it needs community counseling and empowerment, then it needs cross-sector participation and involvement as well as parties who can set an example in society(3).

Most of the reasons for smokers are because it has been a habit for a long time and has been a routine for a long time. The location selection in Latambaga District was based on the consideration that no research had been conducted on the smoking habit of health workers. In addition, in Latambaga Subdistrict itself there are 2 (two) Puskesmas namely Latambaga Puskesmas and Puskesmas Kolakaasi which will be included in the scope of smoking habit research among health workers.

The highest proportion of daily active smokers at the age of 30-34 years was 33.4 percent, more men than women smokers $(47.5 \%$ vs $1.1 \%)$. Based on the type of work, farmers / fishermen / laborers are active smokers every day with the largest proportion $(44.5 \%)$ compared to other occupational groups. The proportion of daily smokers appears to tend to decline in the higher quintiles of the ownership index. The proportion of population aged $=15$ who smoked and chewed tobacco tended to increase in Riskesdas 2007 (34.2\%), Riskesdas 2010 (34.7\%) and Riskesdas 2013 (36.3\%). Compared to the Global Adults Tobacco Survey (GATS) research on the population age group $=15$ years, the proportion of male smokers is 67.0 percent and in the 2013 Riskesdas was 64.9 percent,

Basic Health Research Data (Riskesdas) in 2018 shows that the national smoking prevalence is $24.3 \%$. The prevalence of smoking according to sex, where the prevalence in men is $47.3 \%$ and women are $1.2 \%$. According to the age group, the highest prevalence was at the age of 30-34 at $32.2 \%$, while at the young age / novice smoker (19 years) was $13.4 \%$. According to the place of residence, the prevalence of smoking in rural and urban areas is not too different, however in rural areas it is slightly higher $(25.8 \%)$ than in urban areas $(23.0 \%)$.

The report on the proportion of smoking in the population in Southeast Sulawesi Province according to the 2018 Riskesdas based on the category of daily smokers was $22.3 \%$, occasional smokers $3.7 \%$, former smokers $4.0 \%$, and nonsmokers $70.0 \%$. Whereas in Kolaka Regency, based on the report on the Health Promotion Sector Health Office of Kolaka Regency in 2017, it was known that the proportion of smokers was 9,360 people (48.1\%), in 2018 there were 8,472 (34\%) and in 2019 there were 9,121 people (31\%).(4).

\section{METHOD}

This research is an analytical survey research method using a cross-sectional approach, in which the independent variable and the dependent variable are measured simultaneously. The study was conducted in December 2020 with a population of 106 people and a sample of 84 respondents with all health workers in Latambaga DistrictThe sampling technique uses simple random sampling technique. 


\section{RESULTS}

Table 1 shows that the distribution of respondents based on the benefit category is sufficient, namely as many as 52 people $(61.9 \%)$ and less categories as many as 32 people (38.1\%).

Table 2 shows that the distribution of respondents based on the constraints of the light category is as many as 55 people $(65.5 \%)$ and the heavy category is 29 people $(34.5 \%)$.

Table 3 shows that from 52 respondents based on the benefit category is sufficient, there are 40 people $(76.9 \%)$ who do not smoke and 12 people $(23.1 \%)$ smoke. Of the 32 respondents based on the benefit category less, there were 9 people $(28.1 \%)$ who did not smoke and 23 people $(71.9 \%)$ smoked. The results of data processing performed using the chi square test analysis with a significance level of $95 \%$, the obtained p-value $=0.000<\alpha=0.05$, so Ho is rejected. This means that there is a relationship between the perceived benefits and smoking habits of health workers in the Latambaga District, Kolaka Regency. In addition, the results of the correlation test by looking at the value of phi showed that the closeness of the relationship between benefits and smoking was 0.481 or showed a moderate relationship.

Table 4 shows that of the 55 respondents based on the light category constraints, there are 45 people $(81.8 \%)$ who do not smoke and 10 people (18.2\%) smoke. Of the 29 respondents based on the weight category constraints, there were 4 people (13.8\%) who did not smoke and 25 people $(86.2 \%)$ smoked. The results of data processing performed using the chi square test analysis with a significance level of $95 \%$, the obtained $\mathrm{p}$-value $=0.000<\alpha=0.05$, so Ho is rejected. This means that there is a relationship between the constraints and smoking habits of health workers in the Latambaga District, Kolaka Regency. In addition, the results of the correlation test by looking at the value of phi show that the closeness of the relationship between constraints and smoking habits is 0.656 or indicates a strong relationship.

Table 1

Distribution of Respondents Based on Benefits in the Latambaga Sub-District, Kolaka Regency

\begin{tabular}{|c|c|c|c|}
\hline No. & Benefits & $\mathrm{n}$ & $\%$ \\
\hline 1. & Enough & 52 & 61.9 \\
\hline 2. & Less & 32 & 38.1 \\
\hline & Total & 84 & 100 \\
\hline
\end{tabular}

Source: Primary Data 2020

Table 2

Distribution of Respondents Based on Constraints in the Sub-District of Latambaga, Kolaka Regency

\begin{tabular}{|c|c|c|c|}
\hline No. & Obstacles & $\mathrm{n}$ & $\%$ \\
\hline 1. & Light & 55 & 65.5 \\
\hline 2. & Weight & 29 & 34.5 \\
\hline \multicolumn{2}{|r|}{ Total } & 84 & 100 \\
\hline
\end{tabular}

Source: Primary Data 2020

Indonesian Journal Of Health Sciences Research and Development

Vol. 3, No.1, March 2021

110 
Table 3

Analysis of the Relationship between Health Workers' Benefits and Smoking Habits in the Latambaga Sub-District, Kolaka Regency

\begin{tabular}{|c|c|c|c|c|c|c|c|c|}
\hline \multirow{3}{*}{ No. } & \multirow{3}{*}{ Benefits } & \multicolumn{4}{|c|}{ Smoking habit } & \multirow{2}{*}{\multicolumn{2}{|c|}{ total }} & \multirow{2}{*}{ Statistic test } \\
\hline & & \multicolumn{2}{|c|}{ Not } & \multicolumn{2}{|c|}{ Smoke } & & & \\
\hline & & $\mathrm{n}$ & $\%$ & $\mathrm{n}$ & $\%$ & $\mathrm{n}$ & $\%$ & $\mathrm{X}^{2}$ test $=17.452$ \\
\hline 1. & Enough & 40 & 76.9 & 12 & 23.1 & 52 & 100 & $\mathrm{X}^{2}$ table $=3,841$ \\
\hline 2. & Less & 9 & 28.1 & 23 & 71.9 & 32 & 100 & pvalue $=0.000$ \\
\hline & Total & 49 & 58.3 & 35 & 41.7 & 84 & 100 & $\varphi=0.481$ \\
\hline
\end{tabular}

Source: Primary Data 2020

Table 4

Analysis of the Relationship of Constraints and Smoking Habits of Health Workers in the Latambaga Sub-District, Kolaka Regency

\begin{tabular}{|c|c|c|c|c|c|c|c|c|}
\hline \multirow{3}{*}{ No. } & \multirow{3}{*}{ Obstacles } & \multicolumn{4}{|c|}{ Smoking habit } & \multirow{2}{*}{\multicolumn{2}{|c|}{ total }} & \multirow{2}{*}{ Statistic test } \\
\hline & & \multicolumn{2}{|c|}{ Not } & \multicolumn{2}{|c|}{ Smoke } & & & \\
\hline & & $\mathrm{n}$ & $\%$ & $\mathrm{n}$ & $\%$ & $\mathrm{n}$ & $\%$ & $\mathrm{X}^{2}$ test $=33,406$ \\
\hline 1. & Light & 45 & 81.8 & 10 & 18.2 & 55 & 100 & $\mathrm{X}^{2}$ table $=3,841$ \\
\hline 2. & Weight & 4 & 13.8 & 25 & 86.2 & 29 & 100 & pvalue $=0.000$ \\
\hline & Total & 49 & 58.3 & 35 & 41.7 & 84 & 100 & $\varphi=0.656$ \\
\hline
\end{tabular}

Source: Primary Data 2020

\section{DISCUSSION}

\section{Perceptions of Benefits with Smoking Habits}

If the individual feels himself vulnerable to diseases that are considered serious (serious), he will take certain actions. This action will depend on the benefits felt when taking the action. In general, the benefits of the action determine more than the obstacles that may be found in doing the $\operatorname{action}(5)$.

The results showed that of 52 respondents based on the benefit category sufficient, there were 40 people $(76.9 \%)$ who did not smoke and 12 people $(23.1 \%)$ smoked. Of the 32 respondents based on the benefit category less, there were 9 people (28.1\%) who did not smoke and 23 people (71.9\%) smoked.

The results of data processing performed using the chi square test analysis with a significance level of $95 \%$, were obtained p-value $=0.000<\alpha=0.05$, so Ho is rejected. This means that there is a relationship between the perceived benefits and smoking habits of health workers in the Latambaga Sub-District, Kolaka Regency. In addition, the results of the correlation test by looking at the value of phi showed that the closeness of the relationship between benefits and smoking was 0.481 or showed a moderate relationship.

The results of this study are in line with research conducted by (6) The results of the Spearman test for the variable perception of the benefits of smoking cessation motivation have a significance value of 0.003 ( $p<0.05$ ), which means that there is a relationship between perceptions of the benefits of quitting smoking and motivation to quit smoking.

The research results are in accordance with the theory (7), which explains that the low perception of the benefits of quitting smoking can significantly affect a person's willingness or motivation to quit smoking. This is because the perception of benefits is a strong predictor of the health belief model, which is the background for various choices 
of actions including behavior change to reduce the threat of a disease. The tendency for someone to want to quit smoking can be motivated by an illness that has been suffered before. In addition, the perceived benefits of quitting smoking can also be a contributing factor.

The perceived benefit factor here is a person's belief in the success of the action to quit smoking. 52 respondents have a good perception of the benefits. Most respondents are aware of the advantages and disadvantages of smoking and non-smoking behavior, such as a person will be more economical if they do not smoke because no funds are spent on buying cigarettes. Besides having a negative impact on yourself, smoking can also have an impact on the people around people who smoke, because these people will become passive smokers.

In this study, respondents who tended to have a high self-perception of ability realized the dangers and benefits of smoking, so they avoided smoking. They realized that they could not easily cure a smoking-related disease such as lung disease or heart disease. Even though they are still relatively young, they do not eliminate the possibility that they will also get the disease and regular exercise is not a solution to avoiding the disease if they smoke.

Smokers who have a low perceived benefit will make them quit smoking will be low and that is a barrier for them to quit smoking(8). According to(9), smoking is associated with poverty, alcohol use and unemployment, which can be reasons for them to smoke. The study found that although some people understand that smoking causes damage to their health, some people still believe about the benefits of smoking. The low perception of the benefits of smoking as a health risk can make a person smoke(10).

In this study, people who have a good perceived benefit will leave smoking much more than people who have a poor perception of benefits. Respondents with good perceived benefits mostly realized that they would be more economical if they did not smoke, they would be prone to disease if they inhaled cigarette smoke, their bodies would be healthier if they did not smoke, and they were afraid of lung cancer if they smoked.

\section{Perception of Constraints with Smoking Habits}

Potential aspects of a health measure can become an obstacle to taking the recommended action. Unconsciously, cost and benefit analysis of the effectiveness of health measures, harmful (have negative and iatrogenic side effects) unpleasant (painful, difficult, irritating) uncomfortable, time consuming, etc.(11).

The results showed that of 55 respondents based on the light category constraints, there were 45 people $(81.8 \%)$ who did not smoke and 10 people (18.2\%) smoked. Of the 29 respondents based on the weight category constraints, there were 4 people $(13.8 \%)$ who did not smoke and 25 people $(86.2 \%)$ smoked.

The results of data processing performed using the chi square test analysis with a significance level of $95 \%$, were obtained p-value $=0.000<\alpha=0.05$, so Ho is rejected. This means that there is a relationship between the constraints and smoking habits of health workers in the Latambaga Sub-District, Kolaka Regency. In addition, the results of the correlation test by looking at the value of phi show that the closeness of the relationship between constraints and smoking habits is 0.656 or indicates a strong relationship.

The results of this study are in line with research conducted by (12). The results of hypothesis testing using the Rank Spearman test showed a $\mathrm{p}$ value of $0.045=$ 0.05 , which means that there is a significant relationship between the perceived barrier perceived by respondents in trying to quit smoking and the type of smoking behavior. Research(13), which states that there is a relationship between the perception of 
smoking cessation barriers with the incidence of smoking relapse.

The results of this study are in accordance with the inner Health Belief Model theory (13), which states that the high perception of smoking cessation inhibitors can significantly affect the willingness or motivation of a person to quit smoking. This is because several studies, both retrospective and prospective, show that the high perceived barrier has a very large impact on the dimensions of the Health Belief Model in explaining or predicting a lack of healthmaintaining behavior.

A total of 55 respondents had a good perception of obstacles. Perceptions of barriers are beliefs about real or psychological obstacles to the actions that a person will take. Environmental factors are factors that influence a person's perception of barriers. A person's character is largely shaped by the surrounding environment, both family, neighbors and friends. People who have a high intensity to interact with a smoker will have a high probability to become a smoker because they will be affected because they will have a poor perception of inhibition.

According to Stretcher et al, the perception of barriers to quitting smoking can include a person being afraid of stress when quitting smoking, because they think that smoking is a stress reliever, besides that they are also afraid that their weight will increase and pressure from other smokers (friends or family) also inhibits them. someone not to smoke. Another factor stated by(14), the level of nicotine addiction also affects the perception of inhibition of a man and a woman. According to(15)mentioned that in HBM individuals will take action to prevent or control ill health conditions if they consider themselves vulnerable to a condition. If they believe that the available actions will bring far more benefits, they will leave the barriers behind and take actions that are proportionate to the benefits. In this study, a person who has poor perceptions tends not to smoke.

\section{CONCLUSION}

There is a relationship between perceived benefits and constraints with habits smoking health personnel in the Latambaga Sub-District, Kolaka Regency. So that advicefor leaders in their respective technical units to impose a smoking ban in areas where health services are located, because it will be a bad example for the community in terms of maintaining health.

\section{REFERENCES}

1. Ardini PP. Effect of story and communication to child moral grow in 7-8 years old. Jurnal Pendidikan Anak. 2012;1(1) Indonesia).

2. Sholihah M. Analysis of smoking behavioural change in hipertension patients in Ciputat health centre Tanggerang Selatan. 2014.

3. Jayadipraja EA, Prasetya F, Azlimin A, Mando WOSY. Family clean and healthy living behavior and its determinant factors in the village of Labunia, Regency of Muna, Southeast Sulawesi Province of Indonesia. Public Health of Indonesia. 2018;4(1):39-45.

4. Dinas Kesehatan Kabupaten Kolaka. Promkes Dinas Kesehatan Kabupaten Kolaka Kolaka: Sulawesi Tenggara; 2019.

5. Notoatmodjo S. Health promotion and health behaviour. Jakarta: rineka cipta. 2012:45-62.

6. Kumboyono K. Analysis of factors of barrier of motivaation in stopping of smoking based on Health Belief Model in students in Faculty of Technique, Brawijaya University Malang. Soedirman Journal of Nursing. 2011;6:1-8.

7. Kurniawati C, Sulistyowati M. Aplication of Health Belief Model in prevention of pathology of pale diases. Jurnal Promkes. 2014;2(2):117-27.

8. Grimwood J, Gordon LA, Olsen A, Terry A, Schmutz J, Lamerdin J, et al. The DNA sequence and biology of 
Pingak, M., Tasnim,T., \& Wahab, H.

DOI: 10.36566/ijhsrd/Vol3.Iss1/62

https://ijhsrd.com/index.php/ijhsrd

human chromosome 19. Nature. 2004;428(6982):529-35.

9. Sallis JF, Cervero RB, Ascher W, Henderson KA, Kraft MK, Kerr J. An ecological approach to creating active living communities. Annu Rev Public Health. 2006;27:297-322.

10. Tantri A, Fajar NA, Utama F. The relationship between perseption and warning of smoking effect in cigarrete pack with smoking behaviour in male teenagers in Palembang City. Jurnal Ilmu Kesehatan Masyarakat. 2018;9(1):74-82.

11. Afrianto D. Effect of health promotion to paprika farmer's knowledge, attitude and practice in Kumbo-Pasuruan village with usage of self protection equipments from pesticide effect. 2014.

12. Anisa R. Management of correlation of customer in create clien belief in Bank Mandiri Bandung. Jurnal Kajian Komunikasi. 2016;4(1):43-50.

13. Darojah S. Faktor Determinants of barrier of stop smoking in head of household in Jatiyoso Subdistrict, Karanganyar District: Universitas Muhammadiyah Surakarta; 2014.

14. Alawiyah SS. Overview of perception about electric cigarret in electric cigarret users in Vaporizer community in Tangerang City: UIN Syarif Hidayatullah Jakarta: Fakultas Kedokteran dan Ilmu Kesehatan, 2017; 2017.

15. Larasati H. Deskriptive study of Health Belief in students smokers in Faculty of medicine inUniversitas Islam Bandung: Fakultas Psikologi Universitas Islam Bandung (UNISBA); 2016. 